\title{
UPAYA MENINGKATKAN KOMPETENSI GURU \\ DALAM MENYUSUN RENCANA PELAKSANAAN PEMBELAJARAN BERBASIS LEARNING CYCLE 7E MELALUI SUPERVISI AKADEMIK
}

\author{
Wati Rahayu \\ watirahayu.gr@gmail.com \\ SD Negeri 010 Air Putih, Indragiri Hulu, Indonesia
}

\begin{abstract}
This study aims to improve teacher competency in developing lesson plans based on the 7E learning cycle through academic supervision. The study was conducted at Air Putih 010 Air Putih Elementary School on 13 teachers conducted for 2 months starting from 26 August to 19 October 2019. This class action research design refers to the research design according to Stephen Kemmis and Mc. Taggart consists of 4 stages in each cycle, including: 1) planning, 2) action, 3) observation, and 4) reflection. Data analysis through the stages of data collection, data simplification, data presentation, drawing conclusions. The results showed an increase experienced by teachers namely from the first cycle of $66 \%$ which is included in the category enough to $83 \%$ which is a very good category. Conclusions based on the results and discussion are the competencies of teachers in developing lesson plans based on the $7 E$ learning cycle have increased after academic supervision.
\end{abstract}

Keywords: teacher competence, lesson plan, learning cycle 7E, academic supervision.

\section{ABSTRAK}

Penelitian ini bertujuan untuk meningkatkan kompetensi guru dalam menyusun RPP berbasis learning cycle 7E melalui pelaksanaan supervisi akademik. Pelaksanaan penelitian di SD Negeri 010 Air Putih terhadap 13 orang guru yang dilakukan selama 2 bulan dimulai dari 26 Agustus sampai 19 Oktober 2019. Desain penelitian tindakan kelas ini mengacu pada desain penelitian menurut Stephen Kemmis dan Mc. Taggart yang terdiri atas 4 tahapan pada tiap siklusnya, antara lain: 1) perencanaan, 2) tindakan, 3) observasi, dan 4) refleksi. Analisis data melalui tahapan pengumpulan data, penyederhanaan data, penyajian data, penarikan kesimpulan. Hasil penelitian menunjukkan adanya peningkatan yang dialami guru yakni dari siklus I sebesar $66 \%$ yang termasuk dalam kategori cukup menjadi $83 \%$ yang merupakan kategori baik sekali. Kesimpulan berdasarkan hasil dan pembahasan adalah kompetensi guru dalam menyusun RPP berbasis learning cycle 7E mengalami peningkatan setelah dilakukan supervisi akademik.

Kata Kunci: kompetensi guru, rencana pelaksanaan pembelajaran, learning cycle 7E, supervisi akademik

\begin{tabular}{|c|c|c|}
\hline Submitted & Accepted & Published \\
\hline 30 Juni 2019 & 05 Oktober 2019 & 14 November 2019 \\
\hline
\end{tabular}

\begin{tabular}{|l|c|r|}
\hline Citation & $:$ & $\begin{array}{r}\text { Rahayu, W. (2019). Upaya Meningkatkan Kompetensi Guru dalam Menyusun Rencana Pelaksanaan Pembelajaran Berbasis } \\
\text { Learning Cycle 7e Melalui Supervisi Akademik. Jurnal PAJAR (Pendidikan dan Pengajaran), 3(6), 1304-1312. } \\
\text { DOI : http://dx.doi.org/10.33578/pjr.v3i6.7862. }\end{array}$ \\
\hline
\end{tabular}

\section{PENDAHULUAN}

Tujuan utama dalam pelaksanaan pembelajaran adalah keberhasilan siswa. Keberhasilan akan tercapai apabila dimulai dengan perencanaan, pelaksanaan, dan evaluasi yang baik. Kunci pokok terdapat pada perencanaan, dengan perencanaan yang baik maka proses dan hasil akan baik. Namun jika tanpa perencanaan yang baik maka kendala yang ditemukan dalam proses pembelajaran akan sulit dihadapi karena tidak memiliki gambaran dan manajemen tentang proses dan evaluasi yang akan dilakukan.
Salah satu tugas guru dalam pembelajaran adalah menyiapkan perencanaan pembelajaran yang disebut RPP yakni kegiatan yang terus menerus dan menyeluruh, dimulai dari penyusunan program pembelajaran, pelaksanaan kegiatan pembelajaran, evaluasi pelaksanaan dan hasil yang dicapai dari tujuan yang sudah ditetapkan, dari hasil penilaian dilakukan telaah pencapaian siswa, instrumen yang disusun, serta program pembelajarannya (Kunandar, 2015). Tujuan penyusunan RPP adalah untuk mempermudah, memperlancar dan meningkatkan hasil proses pembelajaran yang dilakukan guru di 
dalam kelas, dengan menyusun RPP secara profesional, sistematis dan berdaya guna, maka guru akan mampu melihat, mengamati, menganalisis, dan memprediksi program pembelajaran sebagai kerangka kerja yang terstruktur, sistemati, logis, dan terencana (Kunandar, 2011).

Dalam penyusunan RPP, guru harus memahami kebutuhan dan kemampuan siswa sehingga tujuan pembelajaran sesuai dengan kurikulum dan kebutuhan siswa. Selain itu pemahaman guru terhadap karakter dan lingkungan siswa juga diperlukan agar guru dapat menerapkan metode atau model pembelajaran yang tepat sesuai kondisi siswa. Dengan kompetensi yang dimiliki guru dalam menganalisis kondisi dan kebutuhan siswa, maka hasil yang baik akan diperoleh dalam pelaksanaan pembelajaran.

Pada kenyataannya, penyusunan RPP di lapangan tidak sesuai standar yang ditetapkan, artinya RPP yang disusun tidak lengkap dan sistematis. Temuan yang peneliti peroleh dari hasil pengamatan di lapangan adalah 1) RPP yang dibuat merupakan salinan copy paste dari tahun sebelumnya, hal ini karena guru menganggap RPP sebagai syarat administrasi semata tanpa mempertimbangkan esensi dan tujuan pembelajaran yang hendak dicapai, 2) guru jarang diberikan bimbingan maupun pelatihan dalam penyusunan RPP sehingga guru mengalami kebingungan dalam membuat RPP yang lengkap dan sistematis, 3) belum adanya supervisi yang dilakukan kepala sekolah maupun pengawas dalam meningkatkan kompetensi guru terutama penyusunan RPP, 4) peran pengawas dan kepala sekolah dalam mengoreksi administrasi guru termasuk RPP menyebabkan penyusunan RPP tidak menjadi permasalahan, padahal RPP merupakan senjata yang dapat dijadikan acuan dan memperbaiki kendala yang terjadi di lapangan sehingga menghasilkan prestasi belajar siswa yang baik.

Lebih lanjut peneliti melakukan studi pendahuluan berupa wawancara dan dokumentasi, peneliti menemukan bahwa: 1) hasil wawancara dengan guru menyatakan bahwa mereka belum memahami penyusunan RPP secara lengkap dan sistematis sehingga guru hanya melakukan copy paste atau perubahan data inti seperti tahun dan kelas dari sebuah RPP yang telah ada, 2) dokumentasi RPP yang telah terkumpul di arsip kemudian dilakukan analisis, sehingga ditemukan bahwa: a) RPP yang disusun belum menggambarkan pembelajaran secara utuh, b) komponen RPP belum lengkap dan sistematis, c) kemampuan guru belum memadai dalam mengembangkan komponen RPP sesuai kebutuhan dan kemampuan siswa, misalnya: guru kurang mampu (1) mengidentifikasi mata pelajaran, (2) merumuskan indikator, (3) merumuskan tujuan pembelajaran, (4) menetapkan materi ajar, (5) memilih referensi, (6) menentukan model pembelajaran, (7) merancang skenario pembelajaran, (8) membuat format penilaian, dan (9) banyak RPP yang dimiliki guru merupakan hasil karya orang lain (copy paste).

Melihat fakta yang ditemukan, perlu adanya tindakan yang dilakukan oleh pengawas maupun kepala sekolah untuk memperbaiki dan meningkatkan kompetensi guru dalam menyusun RPP agar pembelajaran menjadi terarah, menyenangkan, dan menghasilkan siswa yang memiliki prestasi yang baik. Supervisi yang dilakukan oleh wewenang di sekolah diharapkan mampu memecahkan masalah tersebut. Penelitian terdahalu membuktikan bahwa supervisi akademik dapat meningkatkan kompetensi guru dalam menyusun RPP (Rambe, 2019).

Penelitian ini diharapkan dapat meningkatkan kompetensi guru dalam menyusun RPP secara lengkap dan sistematis. RPP dalam penelitian ini dimodifikasi ke dalam model pembelajaran learning cycle 7E, di mana sintaks yang ada pada model pembelajaran ini disisipkan dalam setiap tahapan mulai dari tahapan pendahuluan, isi, sampai tahapan penutup. Untuk mencapai itu maka supervisi diharapkan menjadi metode yang tepat yang dilakukan terhadap guru. 
KAJIAN TEORETIS

\section{Kompetensi Guru}

Dalam menjalankan profesi sebagai pendidik, guru harus memiliki kompetensi sehingga ia mampu memerankan tugas dan fungsinya meningkatkan kemampuan siswa. Undang-Undang Nomor 14 tahun 2005 Pasal 10 tentang Guru dan Dosen mengamanahkan kompetensi yang harus dimiliki guru adalah kompetensi pedagogik, kompetensi kepribadian, kompetensi sosial, dan kompetensi profesional yang diperoleh melalui pendidikan profesi. Kompetensi guru merupakan kemampuan yang ada pada guru sebagai pendidik dan pengajar berupa pengetahuan, keterampilan, dan sikap yang direpresentasikan dalam pembelajaran (Umardulis, 2019 dan Ahmad, 2019). Menurut Hakim (2015) Kompetensi guru diartikan sebagai karakteristik utama yang dimiliki oleh individu dalam setiap bidang profesi yang dapat membantunya berhasil. Berdasarkan pendapat tersebut dapat ditarik kesimpulan bahwa kompetensi guru adalah kemampuan guru yang profesionalitasnya dalam bidang pengajaran dan pendidikan berupa pengetahuan, keterampilan, dan sikap yang dapat menjadikannya berhasil dalam pembelajaran.

Dalam depdiknas 2004 menyebut kompetensi pedagogik guru dalam mengelola pembelajaran dapat dilihat dari kemampuan merencanakan program belajar mengajar, kemampuan melaksanakan interaksi atau mengelola proses belajar mengajar, dan kemampuan melakukan penilaian. Guru yang memiliki kompetensi ini akan mengatur pembelajaran sesuai dengan kondisi dan kemampuan siswa.

\section{Rencana Pelaksanaan Pembelajaran}

Rencana pelaksanaan pembelajaran (RPP) merupakan panduan dari langkah-langkah yang akan dilaksanakan oleh guru dalam proses pembelajaran yang disusun dalam sebuah skenario kegiatan (Yurnalis, 2018). Lebih lanjut Asnidawati (2019) menyatakan RPP adalah sebuah alat yang wajib dimiliki oleh guru untuk melakukan sebuah rencana yang memaparkan prosedur dalam proses pembelajaran di kelas untuk mencapai tujuan yang telah ditetapkan. Merencanakan program belajar mengajar merupakan proyeksi guru mengenai kegiatan yang harus dilakukan siswa selama pembelajaran berlangsung, yang mencakup: merumuskan tujuan, menguraikan deskripsi satuan bahasan, merancang kegiatan belajar mengajar, memilih berbagai media dan sumber belajar, dan merencanakan penilaian penguasaan tujuan.

Menurut Permendiknas Nomor 41 tahun 2007 tentang Standar Proses, komponenkomponen yang harus ada di dalam RPP sekurangkurangnya adalah sebagai berikut: 1) Identitas mata pelajaran; 2) Standar kompetensi; 3) Kompetensi dasar; 4) Indikator pencapaian kompetensi; 5) Tujuan pembelajaran; 6) Materi ajar; 7) Alokasi waktu; 8) Metode pembelajaran; 9) Kegiatan pembelajaran seperti ; pendahuluan, kegiatan Inti, dan Penutup; 10) Penilaian hasil belajar; dan 11) Sumber belajar. Dalam penelitian ini, RPP yang disusun sesuai komponen dimodifikasi dengan model pembelajaran learning cycle 7E yang meliputi elicit (memperoleh), engage (melibatkan), explore (menyelidiki), explain (menjelaskan), elaborate (mengembangkan), evaluate (mengevaluasi), dan extend (memperluas).

Terdapat beberapa prinsip yang harus menjadi perhatian guru, diantaranya memperhatikan perbedaan kemampuan individu siswa, mendorong partisipasi siswa, mengembangkan dan meningkatkan budaya membaca dan menulis siswa, memberikan umpan balik dan tindak lanjut dalam pembelajaran, dan menerapkan teknologi informasi dan komunikasi yang mendukung di dalam proses pembelajaran (Al-Tabany, 2014).

\section{Learning Cycle 7E}

Model learning cycle (7E) adalah pembelajaran siklus yang merupakan salah satu model pembelajaran dengan pendekatan konstruktivis. Implementasi learning cycle dalam pembelajaran menempatkan guru sebagai fasilitator yang mengelola kelangsungan fase-fase tersebut mulai dari perencanaan (terutama perangkat pembelajaran), pelaksanaan (terutama pemberian pertanyaan-pertanyaan arahan dan proses pembimbingan), dan evaluasi (Fajaroh dalam Partini, 2017). Model pembelajaran learning cycle 7E merupakan pembelajaran yang memiliki 7 fase yaitu elicit (memperoleh), engage (melibatkan), explore (menyelidiki), explain (menjelaskan), elaborate (mengembangkan), 
evaluate (mengevaluasi), dan extend (memperluas) (Eisenkraft dalam Miadi, 2019).

\section{Supervisi Akademik}

Dalam rangka mewujudkan pembelajaran yang aktif dan interaksi dua arah antara guru dan siswa, diperlukan kompetensi guru dalam merencanakan dan mengelola pembelajaran. Kompetensi guru dapat ditingkatkan melalui pelatihan, workshop, penugasan, maupun supervisi. Menurut Suriati (2018) dan Suryani (2019) menyatakan supervisi akademik adalah serangkaian kegiatan yang dilakukan sebagai upaya untuk membantu guru dalam mengembangkan kemampuannya mengelola proses pembelajaran untuk mencapai tujuan pembelajaran. Menarik kesimpulan dari pernyataan di atas bahwa supervisi akademik merupakan upaya kepala sekolah maupun pengawas untuk membantu guru dalam meningkatkan kemampuan guru untuk mencapai tujuan pembelajaran.

Supervisi bertujuan untuk membantu guruguru dalam: a) mengembangkan proses

\section{METODE PENELITIAN}

Penelitian ini berlokasi di SD Negeri 010 Air Putih. Subjek penelitian berjumlah 13 orang guru. Pelaksanaan penelitian ini selama 2 bulan dimulai dari 26 Agustus sampai 19 Oktober 2019. Penelitian ini merupakan penelitian tindakan sekolah, desain penelitian mengadopsi dari model Stephen Kemmis dan Mc. Taggart yang terdiri atas 4 tahapan pada tiap siklusnya, antara lain: 1) pembelajaran, lebih memahami kualitas, pertumbuhan dan peranan sekolah; b) menerjemahkan kurikulum ke dalam bahasa pembelajaran; c) melihat tujuan pendidikan, membimbing pengalaman pembelajaran, menggunakan sumber dan metode mengajar memenuhi kebutuhan belajar dan menilai kemajuan belajar siswa, membina moral kerja, menyesuaikan diri dengan masyarakat, dan membina sekolah; dan d) membantu mengembangkan profesional guru dan staf sekolah (Sagala, 2012).

Agar tujuan supervisi yang dilaksanakan dapat tercapai maka harus diperhatikan proses supervisi tersebut telebih dahulu. Adapun prosesnya terdiri dari 10 (sepuluh) dimensi, diantaranya: (1) difokuskan pada tujuan, (2) komunikasi yang memadai, (3) kekuasaan yang sama, (4) pemanfaatan sumber daya, (5) identitas yang jelas, (6) moral, (7) inovatif, (8) otonomi, (9) adaptasi, dan (10) pemecahan masalah (Starrat dalam Samudi, 2018).

perencanaan (planning), 2) tindakan (action), 3) observasi (observation), dan 4) refleksi (reflection). Pada tahap persiapan dibuat skenario kegiatan, jadwal, tempat serta sarana pendukung lainnya seperti lembar observasi (Wadhani dalam Rasmita, 2019). Alur PTS dapat dilihat pada gambar berikut: 


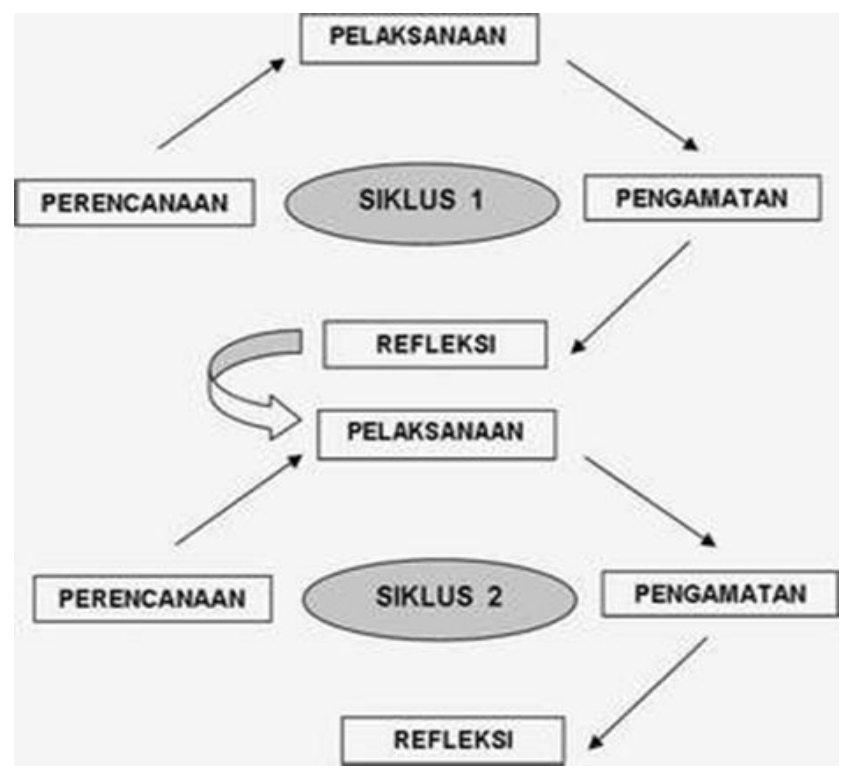

Gambar 1. Alur Penelitian Tindakan Sekolah

Sumber Data, Teknik Pengumpulan Data, dan Analisis Data

Data bersumber dari wawancana dengan guru dan dokumen perangkat RPP yang disiapkan guru. Teknik pengumpulan data meliputi kegiatan observasi, wawancara dan dokumentasi. Analisis data melalui tahapan pengumpulan data, penyederhanaan data (data reduction), penyajian data (data display), penarikan kesimpulan (conclusion drawing). Data dianalisis menggunakan rubrik penilaian disesuaikan dengan model learning cycle 7E, diberi skor 1 jika soal tes tidak sesuai dengan indikator, skor 2 jika kurang, skor 3 jika cukup, skor 4 jika sesuai, skor 5 jika sangat sesuai. Setelah diperoleh data dihitung menggunakan rumus berikut:

Nilai akhir $=\frac{\text { skor perolehan }}{\text { skor maksimal }} \times 100 \%$

(dalam Asnidawati, 2019)

Indikator keberhasilan penelitian ini adalah jika kompetensi guru telah mencapai kategori baik sekali. Adapun kategori kompetensi guru diklasifikasikan dalam tabel berikut:

Tabel 1. Interval dan Kategori Kompetensi Guru dalam Menyusun RPP

\begin{tabular}{cc}
\hline Interval (\%) & Kategori \\
\hline $80-100$ & Baik Sekali \\
$70-79$ & Baik \\
$60-69$ & Cukup \\
$50-59$ & Kurang \\
$\leq 49$ & Kurang Sekali \\
\hline
\end{tabular}

(Sujarno, 2019)

\section{HASIL DAN PEMBAHASAN}

Siklus I

Berdasarkan hasil observasi dan dokumentasi perangkat pembelajaran yang peneliti lakukan, setelah dilakukan supervisi pada siklus I mengenai bimbingan pemnyusunan RPP diperoleh informasi mengenai data perangkat 
yang dikumpulkan guru bahwa rata-rata guru telah menyusun RPP sesuai pedoman yang ditetapkan, ada sedikit guru sudah tampak memasukkan fase-fase model learning cycle 7E dalam tahapan RPP yang disusun, namun secara keseluruhan belum mencerminkan RPP yang lengkap dan sistematis berbasis learning cycle 7E yang dibimbing oleh peneliti.

Data yang diperoleh merupakan perangkat RPP yang disusun oleh guru dengan materi sesuai kelas yang diampu oleh masingmasing. Data tersebut dinilai sesuai dengan pedoman yang telah ditetapkan. Data ini digunakan untuk mengukur seberapa besar kompetensi guru pada tiap siklus dan dapat dilihat perbandingan dan peningkatan dari siklus I ke siklus berikutnya. Berikut data hasil observasi terhadap perangkat RPP yang disusun oleh guru pada siklus I:

Tabel 2. Rekapitulasi Hasil Penilaian Penyusunan RPP Guru Siklus I

\begin{tabular}{|c|c|c|c|c|c|c|c|c|c|c|c|c|c|c|}
\hline \multirow[b]{2}{*}{ No } & \multirow{2}{*}{ Guru } & \multicolumn{11}{|c|}{ Komponen RPP berbasis learning cycle 7E } & \multirow{2}{*}{$\begin{array}{c}\text { Rata-rata } \\
\text { individu } \\
(\%)\end{array}$} & \multirow{2}{*}{ Kategori } \\
\hline & & (1) & (2) & (3) & (4) & (5) & (6) & (7) & (8) & (9) & (10) & (11) & & \\
\hline 1. & $\mathrm{~A}$ & 3 & 3 & 3 & 2 & 3 & 4 & 4 & 3 & 2 & 2 & 2 & 56 & Kurang \\
\hline 2. & $\mathrm{~B}$ & 4 & 4 & 4 & 3 & 4 & 4 & 4 & 4 & 3 & 3 & 3 & 72 & Baik \\
\hline 3. & $\mathrm{C}$ & 3 & 3 & 3 & 2 & 2 & 3 & 3 & 2 & 2 & 2 & 3 & 50 & Kurang \\
\hline 4. & $\mathrm{D}$ & 4 & 3 & 4 & 3 & 3 & 4 & 4 & 3 & 3 & 3 & 3 & 67 & Cukup \\
\hline 5. & $\mathrm{E}$ & 3 & 3 & 3 & 3 & 3 & 4 & 4 & 3 & 3 & 3 & 3 & 63 & Cukup \\
\hline 6. & $\mathrm{~F}$ & 4 & 3 & 4 & 4 & 4 & 4 & 4 & 4 & 3 & 3 & 4 & 74 & Baik \\
\hline 7. & $\mathrm{G}$ & 3 & 4 & 3 & 4 & 4 & 3 & 3 & 3 & 3 & 3 & 3 & 65 & Cukup \\
\hline 8. & $\mathrm{H}$ & 4 & 3 & 3 & 4 & 4 & 4 & 4 & 4 & 4 & 3 & 4 & 74 & Baik \\
\hline 9. & I & 3 & 3 & 3 & 3 & 3 & 4 & 4 & 3 & 2 & 3 & 3 & 61 & Cukup \\
\hline 10. & $\mathrm{~J}$ & 3 & 4 & 3 & 4 & 4 & 4 & 4 & 3 & 3 & 4 & 3 & 70 & Baik \\
\hline 11. & $\mathrm{~K}$ & 4 & 3 & 4 & 3 & 3 & 4 & 5 & 4 & 4 & 3 & 4 & 74 & Baik \\
\hline 12. & $\mathrm{~L}$ & 3 & 4 & 4 & 3 & 4 & 4 & 4 & 3 & 3 & 3 & 3 & 69 & Cukup \\
\hline \multirow[t]{2}{*}{13.} & M & 3 & 3 & 4 & 3 & 4 & 4 & 3 & 4 & 3 & 3 & 3 & 67 & Cukup \\
\hline & $\begin{array}{c}\text { Rata-rata } \\
\text { komponen } \\
(\%)\end{array}$ & 67 & 66 & 69 & 63 & 69 & 76 & 76 & 66 & 58 & 58 & 63 & 66 & Cukup \\
\hline
\end{tabular}

\section{Keterangan:}

Komponen RPP: (1) Identitas mata pelajaran; (2) Standar kompetensi; (3) Kompetensi dasar; (4) Indikator pencapaian kompetensi; (5) Tujuan pembelajaran; (6) Materi ajar; (7) Alokasi waktu; (8) Metode pembelajaran; (9) Kegiatan pembelajaran seperti ; pendahuluan, kegiatan Inti, dan Penutup; (10) Penilaian hasil belajar; dan (11) Sumber belajar.

Berdasarkan data hasil penilaian penyusunan RPP berbasis learning cycle 7E yang dibuat oleh guru dapat dilihat bahwa rata-rata kompetensi guru adalah sebesar 66\% dengan kategori cukup, terdapat 2 orang guru memiliki kompetensi kurang, 6 orang memiliki kategori cukup, dan 5 orang mencapai kategori baik. Komponen RPP memiliki 7 komponen termasuk kategori cukup, 2 komponen yang termasuk kurang yakni kegiatan pembelajaran dan penilaian hasil belajar, serta 2 komponen yang termasuk baik yaitu materi ajar dan alokasi waktu.

Berdasarkan data tersebut, peneliti melihat bahwa kemampuan guru dalam mengembangkan perangkat RPP masih harus diperbaiki, merujuk pada catatan bahwa masih banyak guru yang belum mencantumkan identitas mata pelajaran dengan lengkap, ada juga guru yang tidak mencantumkan SK \& KD dengan baik, padahal ini bisa dilihat dari RPP terdahulu maupun buku panduan materi ajar, masih banyak guru yang belum memahami indikator dan tujuan pembelajaran, padahal ini merupakan hal penting agar target kita dalam mengajar menjadi jelas, untuk materi ajar dan alokasi waktu sudah disusun dengan baik hanya saja materi tidak mencantumkan sub baba tau bagian yang perlu diajarkan tiap pertemuannya, juga alokasi masih 
bersifat umum, sebaiknya alokasi disusun sesuai kegiatan baik pada pendahuluan, isi, maupun penutup. Masih banyak guru yang belum mampu memilih metode pembelajaran yang mampu meningkatkan aktifitas siswa padahal jika guru memahami fase pembelajaran dalam learning cycle 7E maka guru akan mampu menyusun proses pembelajaran dari awal hingga akhir, guru juga tidak mencantumkan tes maupun kriteria penilaian di akhir pertemuan serta tidak mencantumkan sumber ajar yang memadai sehingga evaluasi siswa kurang memadai.

Berdasarkan hasil penilaian terhadap RPP yang disusun oleh guru yang termasuk kategori cukup, perlu dilakukan telaah terhadap permasalahan dan kendala yang dihadapi guru. Upaya yang dapat dilakukan adalah mereviu kembali RPP guru dan melakukan pembimbingan secara intensif terhadap kendala yang dihadapi. Setiap tahapan pelaksanaan dilihat dan dilakukan refleksi agar dapat dijadikan sebagai pertimbangan perbaikan pada siklus berikutnya. Salah satu upaya kongkrit berdasarkan hasil refleksi adalah memberikan contoh RPP berbasis learning cycle 7E yang di setiap tahapannya terdapat fase learning cycle 7E.

\section{Siklus II}

Siklus II merupakan perbaikan berdasarkan hasil refleksi dari siklus I di mana pada siklus II guru diharapkan dapat menyusun RPP secara lengkap dan sistematis yang telah dimodifikasi dengan model pebelajaran learning cycle 7E. Adapun hasil penyusunan RPP setelah dilakukan perbaikan pada siklus II dapat dilihat pada tabel berikut:

Tabel 3. Rekapitulasi Hasil Penilaian Penyusunan RPP Guru Siklus II

\begin{tabular}{|c|c|c|c|c|c|c|c|c|c|c|c|c|c|c|}
\hline \multirow[b]{2}{*}{ No } & \multirow{2}{*}{ Guru } & \multicolumn{11}{|c|}{ Komponen RPP berbasis learning cycle 7E } & \multirow{2}{*}{$\begin{array}{c}\text { Rata-rata } \\
\text { individu } \\
(\%)\end{array}$} & \multirow[b]{2}{*}{ Kategori } \\
\hline & & (1) & (2) & (3) & (4) & (5) & (6) & (7) & (8) & (9) & (10) & (11) & & \\
\hline 1. & A & 5 & 4 & 4 & 3 & 4 & 4 & 5 & 4 & 4 & 3 & 3 & 78 & Baik \\
\hline 2. & B & 4 & 4 & 5 & 4 & 4 & 5 & 5 & 5 & 4 & 5 & 4 & 89 & Baik sekali \\
\hline 3. & $\mathrm{C}$ & 4 & 4 & 5 & 3 & 4 & 4 & 3 & 3 & 4 & 4 & 5 & 78 & Baik \\
\hline 4. & $\mathrm{D}$ & 4 & 4 & 4 & 3 & 4 & 4 & 4 & 4 & 3 & 4 & 5 & 78 & Baik \\
\hline 5. & $\mathrm{E}$ & 5 & 5 & 4 & 5 & 3 & 4 & 4 & 3 & 5 & 3 & 4 & 81 & Baik sekali \\
\hline 6. & $\mathrm{~F}$ & 5 & 4 & 4 & 5 & 4 & 5 & 5 & 4 & 3 & 3 & 4 & 83 & Baik sekali \\
\hline 7. & $\mathrm{G}$ & 4 & 5 & 3 & 5 & 5 & 4 & 4 & 4 & 5 & 4 & 4 & 85 & Baik sekali \\
\hline 8. & $\mathrm{H}$ & 4 & 5 & 5 & 4 & 4 & 4 & 4 & 5 & 5 & 4 & 4 & 87 & Baik sekali \\
\hline 9. & I & 5 & 4 & 4 & 4 & 4 & 5 & 5 & 4 & 4 & 4 & 3 & 83 & Baik sekali \\
\hline 10. & $\mathbf{J}$ & 4 & 4 & 5 & 4 & 5 & 4 & 4 & 4 & 5 & 4 & 4 & 85 & Baik sekali \\
\hline 11. & $\mathrm{~K}$ & 5 & 4 & 4 & 4 & 4 & 5 & 5 & 4 & 4 & 5 & 4 & 87 & Baik sekali \\
\hline 12. & $\mathrm{~L}$ & 4 & 4 & 4 & 5 & 4 & 4 & 4 & 5 & 3 & 5 & 4 & 83 & Baik sekali \\
\hline \multirow[t]{2}{*}{13.} & M & 4 & 4 & 4 & 5 & 5 & 4 & 5 & 4 & 5 & 4 & 5 & 89 & Baik sekali \\
\hline & $\begin{array}{l}\text { Rata-rata } \\
\text { komponen } \\
(\%)\end{array}$ & 87 & 84 & 84 & 83 & 83 & 86 & 87 & 81 & 83 & 80 & 81 & 83 & Baik sekali \\
\hline
\end{tabular}

Berdasarkan data hasil penilaian penyusunan RPP yang dibuat oleh guru pada siklus II terlihat bahwa ada peningkatan dari siklus I. Pada siklus II rata-rata kompetensi guru dalam menyusun RPP adalah sebesar 83\% yang termasuk kategori baik sekali. Peningkatan ini merupakan efek dari supervisi yang dilakukan oleh peneliti dalam mengupayakan perbaikan dalam pembelajaran khususnya pada perencanaan pembelajaran.
Hampir semua guru memperoleh kategori baik sekali dalam penyusunan RPP, hal ini mencerminkan bahwa kompetensi guru mengalami peningkatan dalam penyusunan RPP. Terlihat dari hasil pengamatan bahwa pada komponen identitas pembelajaran telah memuat data secara lengkap, SK \& KD sudah mengacu pada kurikulum yang diterapkan di sekolah, masing masing guru telah membuat indikator ketercapaian pembelajaran yang ingin dicapai 
sesuai dengan materi masing-masing dan tingkat kemampuan siswa yang bervariasi, tujuan pembelajaran sudah mencerminkan pencapaian yang diharapkan pada indikator yang ditetapkan, materi ajar dan alokasi sudah tersusun sistematis sesuai dengan tahapan dalam komponen RPP yang berbasis learning cycle 7E, guru sudah memahami fase model pembelajaran learning cycle $7 \mathrm{E}$ sehingga mampu memadukan ke dalam proses pembelajaran di mana pada kegiatan pendahuluan guru memasukkan fase elicit dan engage yang merupakan kegiatan siswa memperoleh stimulus pembelajaran dan melibatkan siswa di dalamnya seperti melakukan demonstrasi, pada tahap kegiatan inti guru memasukkan fase explore, explain, dan elaborate, dimana pada fase explore siswa diminta melakukan penyelidikan suatu fenomena sederhana berkaitan materi yang dipelajari, pada fase explain siswa diberikan kesempatan untuk menjelaskan hasil penyelidikan

\section{SIMPULAN DAN REKOMENDASI}

Berdasarkan hasil dan pembahasan yang telah dikemukakan di atas dapat ditarik kesimpulan bahwa kompetensi guru dalam menyusun RPP berbasis learning cycle 7E mengalami peningkatan setelah dilakukan supervisi akademik. Peningkatan yang terjadi adalah kompetensi guru pada siklus I sebesar 66\% dengan kategori cukup menjadi sebesar $83 \%$ yang termasuk dalam kategori baik sekali.

Atas dasar kesimpulan yang dibuat maka

\section{DAFTAR PUSTAKA}

Ahmad, E. (2019). Upaya Meningkatkan Kompetensi Pedagogik Guru dalam Menerapkan Proses Pembelajaran Berbasis Pendekatan Saintifik melalui Supervisi Kunjungan Kelas di SMPN 18 Dumai. Jurnal PAJAR (Pendidikan dan Pengajaran), 3 (4), 859-869.

Al-Tabany., \& Trianto, I. B. (2014). Mendesain Model Pembelajaran Inovatif, Progresif dan Kontekstual. Jakarta: Prenadamedia Group.

Asnidawati. (2019). Kompetensi Guru dalam Menyusun Rencana Pelaksanaan Pembelajaran (RPP) Melalui Supervisi yang dilakukan, pada fase elaborate siswa diminta mengembangkan pengetahuan dan pemahamannya mengenai materi yang dipelajari ke dalam materi atau fenomena yang ada di lingkungan sekitarnya, pada tahap akhir guru memasukkan fase evaluate dan extend dimana pada fase ini siswa melalui bimbingan guru melakukan evaluasi terhadap materi yang dipelajari kemudian memperluas ke pemahaman yang lain yang ada kaitannya dengan materi yang dipelajari.

Peningkatan yang dialami guru dalam menyusun RPP melalui supervisi akademik juga dibuktikan oleh Rambe (2019) karena peneliti melakukan analisis dan bimbingan terhadap kendala yang dihadapi oleh guru. Selain itu Sujarno (2019) menambahkan guru yang biasanya tidak mengumpulkan RPP menjadi bertanggung jawab dalam membuat dan mengumpulkan RPP secara lengkap dan sistematis.

peneliti merekomendasikan agar penelitian selanjutnya mengupayakan kreatifitas guru dalam menyusun perangkat pembelajaran dengan model pembelajaran lain maupun dikombinasikan dengan pembuatan alat peraga sehingga pembelajaran akan menjadi lebih interaktif dan lebih bermakna bagi siswa SD. Pada akhirnya prestasi belajar siswa sejalan dengan proses pembelajaran yang dilakukan dengan maksimal.

Akademik di SD Negeri 004 Sungai Manau. Jurnal PAJAR (Pendidikan dan Pengajaran), 3 (5), 1120-1128.

Hakim, A. (2015). Contribution of Competence Teacher (Pedagogical, Personality, Professional Competence and Social) on the Performance of Learning. The International Journal of Engineering and Science, 4 (2), 01-12.

Kunandar. (2011). Guru Profesional, Implementasi Kurikulum Tingkat Satuan Pendidikan (KTSP) dan Persiapan 
Menghadapi Sertifikasi Guru. Jakarta: Raja Grafindo Persada

Kunandar. (2015). Penilaian Autentik. Suatu Pendekatan Praktis. Jakarta: PT Raja Gafindo Persada.

Miadi, O., Kaniawati, I., Ramalis, T, R. (2019). Penerapan Model Pembelajaran $L C 7 E$ dengan Pendekatan TBCT dan CT untuk Meningkatkan Kemampuan Memahami Siswa. JNSI: Journal of Natural Science and Integration 2 (1), 85 -94.

Partini, dkk. (2017). Penerapan Model Pembelajaran Learning Cycle $7 E$ untuk Meningkatkan Kemampuan Berpikir Kritis Siswa. Jurnal Pendidikan: Teori, Penelitian, dan Pengembangan, 2 (2), 268-272.

Rambe, M. (2019). Pelaksanaan Supervisi Akademik Sebagai Upaya untuk Meningkatkan Kompetensi Guru dalam Menyusun Rencana Pelaksanaan Pembelajaran. Jurnal PAJAR (Pendidikan dan Pengajaran), 3 (4), 782-790.

Rasmita, D. (2019). Upaya Meningkatan Kompetensi Guru dalam Pelaksanaan Proses Pembelajaran Melalui Supervisi Akademik di SD Negeri 017 Pasir Emas. Jurnal PAJAR (Pendidikan dan Pengajaran), 3 (3), 560569.

Sagala, S. (2012). Konsep dan Makna Pembelajaran. Bandung: Alfabeta.

Samudi. (2018). Penerapan Supervisi Akademik Sebagai Upaya untuk Meningkatkan Kinerja
Guru Sekolah Dasar. Jurnal PAJAR (Pendidikan dan Pengajaran), 1 (1), 142149.

Sujarno. (2019). Peningkatan Kompetensi Guru dalam Menyusun Silabus dan RPP melalui Supervisi Akademik di SMP Negeri 3 Sungai Lalak. Jurnal PAJAR (Pendidikan dan Pengajaran), 3 (4), 819-829.

Suriati. (2018). Meningkatkan Kompetensi Guru SDN 007 Kampung Baru Kecamatan Cerenti dalam Menyusun Perencanaan Pembelajaran Melalui Supervisi Akademik. Jurnal PAJAR (Pendidikan dan Pengajaran), 2 (2), 274.

Suryani, L. (2019). Upaya Meningkatkan Kompetensi Guru SMP dalam Menyusun Tes Hasil Belajar Berbasis Keterampilan Berpikir Kritis melalui Supervisi Akademik. Jurnal PAJAR (Pendidikan dan Pengajaran), 3 (4), 773-781.

Umardulis. (2019). Peningkatan Kompetensi Guru Menggunakan Teknologi Informasi dan Komunikasi (TIK) dalam Pembelajaran di Sekolah Dasar melalui Supervisi Klinis. Jurnal PAJAR (Pendidikan dan Pengajaran), 3 (4), 870-878.

Yurnalis. (2018). Upaya Meningkatkan Kemampuan Guru Dalam Menyusun Perangkat Pembelajaran Melalui Supervisi Klinis di Sekolah Binaan Kecamatan Cerenti. Jurnal PAJAR (Pendidikan dan Pengajaran), 2 (4), 505-515. 